\title{
FEEDING IN EBALIA TUBEROSA (Pennant) (CRUSTACEA : DECAPODA : LEUCOSIIDAE)
}

\author{
PATRICK J. SCHEMBRI ${ }^{1}$ \\ University Marine Biological Station, Millport, Isle of Cumbrae, Scotland KA28 OEG
}

\begin{abstract}
Analysis of stomach contents showed the diet of Ebalia tuberosa (Pennant) to consist of small invertebrates, mainly annelids and crustaceans, although organic debris, plant material, and sediment were also present. The crabs fed by probing the topmost layer of sediment with the chelae and captured and ingested any small invertebrates that they disturbed. Occasionally, small, slow-swimming crustaceans were stalked and captured. The crabs also fed on recently dead or moribund organisms. Crabs buried in the sediment showed little response to the presence of a living worm or to a model worm but following addition of food extract, the majority of crabs emerged and attacked both worm and model provided that they moved. Significantly more crabs moved upstream when in a current of water carrying food extract than when no extract was present in the current.
\end{abstract}

\section{INTRODUCTION}

Feeding in brachyuran decapods has been the subject of numerous studies, the majority of which deal with commercially important or common species or species with specialized feeding habits. Little information is available on other less wellknown brachyurans. The family Leucosiidae has about 40 living genera (Warner, 1977) and an almost world-wide distribution, but apart from the casual observations of feeding in Philyra laevis by Hale (1926) and a brief statement on Iliacanthus (Warner, 1977), the feeding biology of leucosiids has not been studied.

Ebalia tuberosa (Pennant) is a typical leucosiid crab and lives in subtidal muddygravels. Adults reach a carapace length of $12-16 \mathrm{~mm}$. The crabs are active at night when they forage for food, but burrow in the sediment during the day (Gosse, 1856; Schembri, 1980). The present paper describes the feeding behaviour of $E$. tuberosa. The crabs feed by capturing small invertebrates living in or on the sediment and by scavenging. Simple experiments were made to determine the relative importance of chemical and mechanical or visual cues in eliciting feeding and in the detection of prey organisms. The ability of the crabs to locate food chemically by moving upcurrent towards the source of the stimulus was also tested.

\footnotetext{
1 Present address: Portobello Marine Laboratory, P.O. Box 8, Portobello, New Zealand.
} 


\section{MATERIAL AND METHODS}

Crabs were collected by dredging at depths of $\approx 44 \mathrm{~m}$ off Farland Point, Isle of Cumbrae, Scotland. The animals were kept in aquaria containing muddy-gravel and supplied with circulating sea water; they were fed every $3-4$ days on scallop meat and polychaete worms.

\section{ANALYSIS OF STOMACH CONTENTS}

Crabs were killed and fixed in $70 \%$ ethanol within $2 \mathrm{~h}$ of collection. The stomachs were dissected out and the contents mounted in a $1: 1$ mixture of glycerol and $70^{\circ}$, ethanol and examined under a compound microscope.

\section{FEEDING BEHAVIOUR}

For observation, crabs were placed in a Perspex aquarium (length $30 \mathrm{~cm} \times$ width $20 \mathrm{~cm} \times$ depth $20 \mathrm{~cm}$ ) containing muddy-gravel from the Farland Point site. Behaviour sequences were filmed with a closed-circuit television camera and recorded on videotape. A red $60-\mathrm{W}$ tungsten lamp providing an illumination of $\approx 40$ lux was the only light source used for observation and filming.

\section{FOOD DETECTION}

Crabs were starved for 3 days and then placed in an aquarium (length $40 \mathrm{~cm} \times$ width $30 \mathrm{~cm} \times$ depth $13 \mathrm{~cm}$ ) containing sea water and a $3-\mathrm{cm}$ layer of sieved gravel (particle size $2-4 \mathrm{~mm}$ ) that had been previously washed and air-dried; the water was not aerated or circulated. Five batches each of five males and five females were used for each experiment. The crabs were placed in the aquarium with the room lights on and allowed to burrow; individuals which did not burrow within $30 \mathrm{~min}$ were replaced. After at least $15 \mathrm{~min}$ after the last crab had burrowed, the room lights were switched off. Observations were made from behind a blind using the available light from a nearby window ( $\approx 40$ lux at the water's surface).

In the first experiment the crabs were presented in turn with (1) an empty stoppered glass tube (length $5 \mathrm{~cm} \times$ diameter $1 \mathrm{~cm}$ );(2) the same tube containing a single intact polychaete (Platynereis); (3) an unconfined polychaete. In the second experiment the crabs were again presented with an unconfined worm but after $5 \mathrm{~min}$. the worm was injured by piercing it with a fine needle. In the third experiment the crabs werc presented with an unconfined worm and after $5 \mathrm{~min}$ two drops of Chlamy's extract ( $C$. opercularis (L.) mantle tissue macerated in sea water and filtered) were added. For the fourth experiment the crabs were tested individually. Each crab was presented with a model polychaete (a $1-\mathrm{cm}$ piece of green polythene tubing tied to fine metal wire) for $30 \mathrm{~s}$. After a 10 -min rest period, two drops of Chlamys extract were added and the model again presented. 


\section{OLFACTION}

The apparatus used consisted of a glass tube (length $17 \mathrm{~cm} \times$ diameter $2.8 \mathrm{~cm}$ ). One end of the tube extended into a tank (length $25 \mathrm{~cm} \times$ width $25 \mathrm{~cm} \times$ depth $15 \mathrm{~cm}$ ) in which running sea water continuously flushed away water from the tube. The other end was fitted with a nozzle connected to a constant head device via two identical glass test-tubes one of which contained a piece of $C$. opercularis mantle tissue and the other acted as a control. The water flow could be switched from one test-tube to the other by means of a 3-way tap (Fig. 1). The experimental tube was

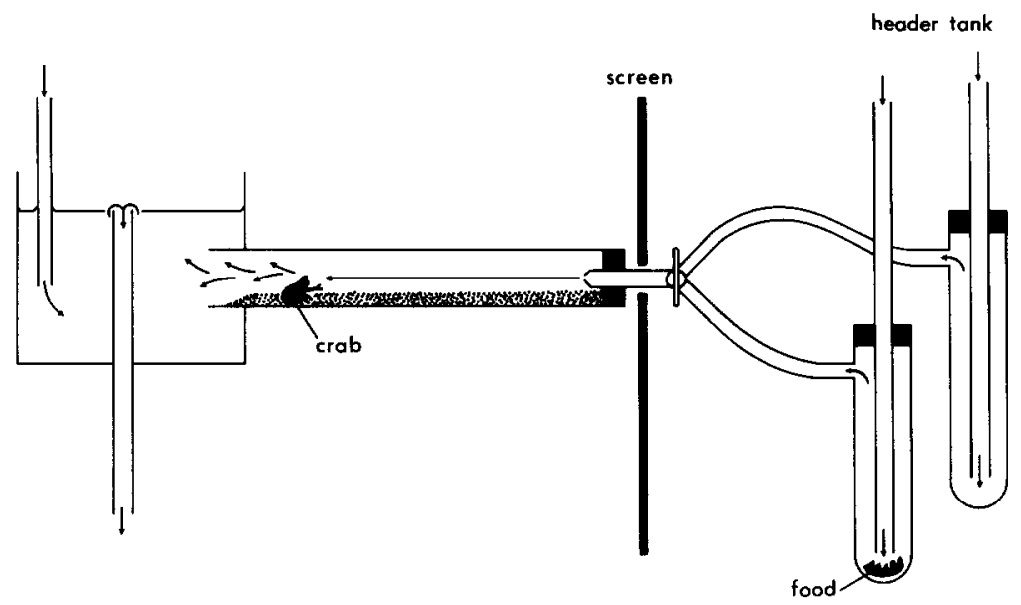

Fig. 1. Apparatus used in olfaction experiments.

screened and illumination was provided by a red 60 -W tungsten lamp. The experimental tube was marked $11 \mathrm{~cm}$ from the nozzle end. The flow rate through the nozzle was $0.92 \mathrm{ml} \cdot \mathrm{s}^{-1}$ and dye tracers showed that this produced a laminar flow down the middle of the experimental tube.

Starved crabs were measured and then placed in the experimental tube facing the nozzle $\approx 2 \mathrm{~cm}$ downstream from the $11-\mathrm{cm}$ mark. When handled the crabs retracted the appendages; as soon as the antennules were extended again, the water current was turned on and the response of the crabs to the current, their direction of movement and the time taken to reach the nozzle after passing the $11-\mathrm{cm}$ mark were noted. Seventy-five crabs were tested with Chlamys extract in the water and 55 without extract. 


\section{RESIIITS}

\section{ANALYSIS OF STOMACH CONTENTS}

Of the 46 stomachs examined ( 21 males, 25 females) 6 were completely full, 11 were half full and the remainder were empty or nearly so. These nearly empty stomachs still contained a few annelid and crustacean setae and small amounts of inorganic particles.

Apart from frequency of occurrence in the stomachs (Table I), no quantitative estimates of relative dietary importance were made but crustacean and annelid

TABLI I

Diet of Ebalia tuberosa based on analyses of the stomach contents of 46 individuals from Farland Point, Isle of Cumbrae, Scotland.

\begin{tabular}{lc}
\multicolumn{1}{c}{ Food item } & $\%$ occurrence \\
\hline Amorphous organic debris & 13.0 \\
Crustacean appendages and other fragments & 15.2 \\
Crustacean setae & 71.7 \\
Annelid uncini and jaws & 21.7 \\
Annelid setae & $34 . x$ \\
Foraminiferans & 6.5 \\
Plates, spicules, spines etc. & 6.5 \\
Plant material & 6.5 \\
Mineral particles & 71.7 \\
\hline
\end{tabular}

fragments appeared to be the most important items in terms of volume. Crustacean fragments included appendages, pieces of exoskeleton, and various types of setae and often the remains present suggested that whole animals, probably amphipods, had been consumed. Identifiable annelid remains included jaws, uncini, and setae of ampharetid, terebellid, eunicid, and sabellid polychaetes. Mineral particles ranged in size from fine sand to silt grade grains. Small quantities of foraminiferans and unidentified inorganic fragments of obvious organic origin (spicules, perforated plates, spines) were occasionally present. Organic debris included muscle fibres, oil globules and cellular material while plant fragments included diatoms, algal filaments, and fragments of macroalgae and bryophytes.

\section{FEEDING BEHAVIOUR}

Three types of feeding were observed: (1) foraging on organisms in the sediment, (2) predation on swimming organisms, and (3) scavenging. Foraging was the most commonly observed of the three and took place during periods of nocturnal activity. The crabs moved slowly on the substratum probing it with the dactyls of the chelipeds (Fig. 2a). Occasionally a little sediment was transferred to the mouth 

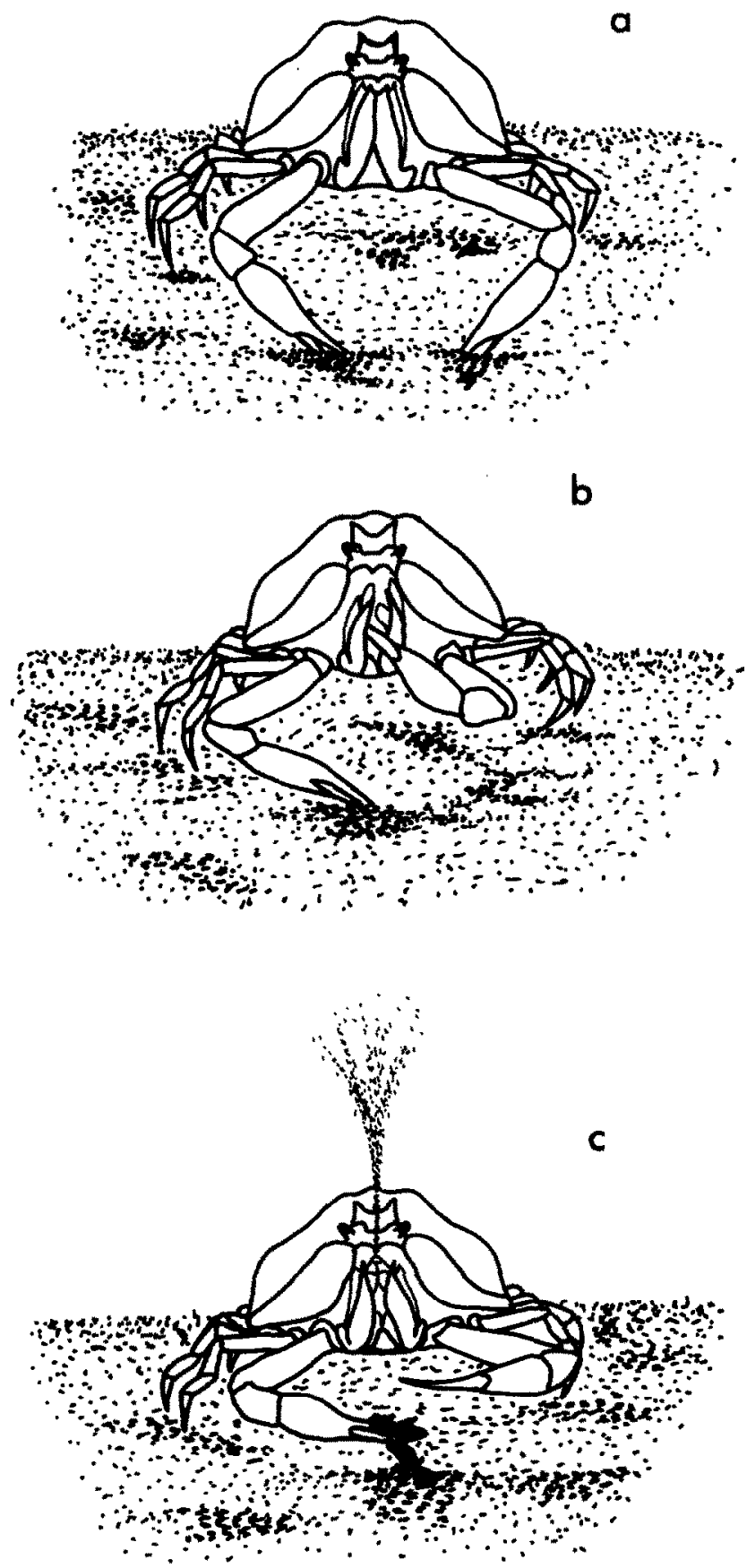

Fig. 2. Frontal views of male Ebalia tuberosa foraging on the sediment: a, probing the sediment; $b$, transferring sediment to the mouthparts; $c$, capturing prey and rejecting particles in the exhalant stream; drawn from videotape recordings and from life; scale bar, $1 \mathrm{~cm}$. 
(Fig. 2b) and then rejected with the powerful exhalant stream (Fig. 2c). Small organisms, mainly amphipods and polychaetes. disturbed during this process were caught with the chelae and eaten (Fig. 2c). Very infrequently the crabs appeared to ingest sediment by conveying pincerfuls of material to the mouth with the chelipeds which worked in alternation. During this process, much material was rejected via the exhalant stream (Fig. 2c)

Predation on swimming organisms was observed less frequently. When some small organism swimming at $\approx 2 \mathrm{~cm}$ or less off the bottom approached a foraging Ehatia, the crab stopped all movement and assumed a posture with the spread chelae held above the body, open pincers and body raised up on the dactyls of the walking legs (Fig. 3a). In this posture the crab stalked the prey until within striking distance and then captured it by a sudden lunge of the chelipeds (Fig. $3 b$ ).
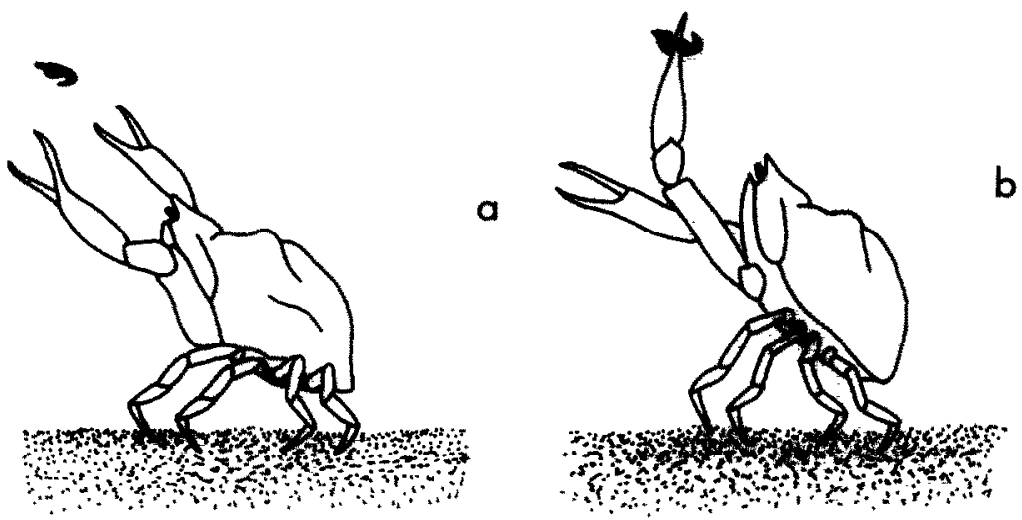

Fig. 3. Male Ehalia tuberosa stalking (a) and capturing (b) a small swimming crustacean: drawn from life: scale bar, $1 \mathrm{~cm}$.

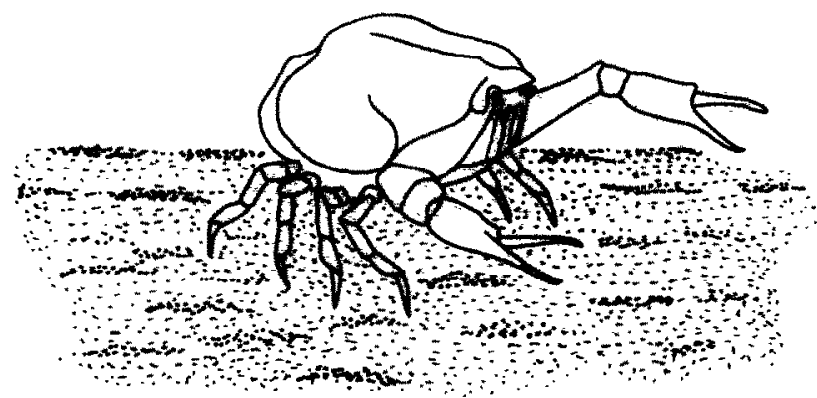

Fig. 4. Female Ebalia tuberosa in the "chelae stretch" posture: drawn from videotape recordings and from life: scale bar. $1 \mathrm{~cm}$. 
Scavenging was observed when the crabs were fed on pieces of scallop meat or on polychaetes. In the presence of food the crabs emerged from the sediment, assumed a posture here called "chelae stretch" and searched about for the food. The "chelae stretch" posture was similar to that adopted when stalking swimming prey except that the chelipeds were stretched forwards in front of the body and held parallel to the surface of the substratum (Fig. 4). Fights between individuals searching for food were frequently observed. Fights were also observed when one crab tried to steal food from another, particularly when both individuals were of similar size. When the size difference was pronounced, the larger crab prevented the smaller one from approaching by pushing it and holding it away with one of the chelae and/or the pereiopods. Scavenging behaviour was observed even during the day when Ebalia tuberosa were normally inactive.

Crabs starved for 3 days did not feed on decaying animal matter or on plant material. No predation on ophiuroids, small asteroids, holothurians, ascidians, small gastropods and bivalves, nemertines, hydroids or small anthozoans kept with the unfed crabs was observed.

\section{FOOD DETECTION}

In the first experiment the glass tube was ignored by all crabs tested both when empty and when it contained a worm. $98 \%$ of the crabs also ignored the unconfined worm even when this made contact with them. In the other experiments the unconfined worm was similarly ignored. The presence of an injured worm or of an intact worm and Chlamys extract, however, caused 80 and $84 \%$, respectively, of the crabs to emerge from the sediment and adopt the "chelae stretch" posture. The crabs appeared to move about randomly and only orientated towards the worm when $\approx 5 \mathrm{~cm}$ away if the worm were moving. When presented with the model polychaete, $24 \%$ of the crabs tested responded by lunging at it with the chelae but a significantly larger number responded $\left(72 \% ; \chi_{c}^{2}=21.19, P \ll 0.001\right)$ when Chlamys extract was also present.

\section{OLFACTION}

The majority of crabs responded to the water current by moving a distance of at least one body length away from their initial position when the current carried extract, however, significantly fewer crabs responded in the control experiment $\left(\chi_{\mathrm{c}}^{2}=23.63 ; P<0.001\right)$ (Table II). In the control group, a similar number of crabs moved away from the nozzle as moved towards it, but significantly more crabs moved towards the nozzle than away from it in the experimental group $\left(\chi_{\mathrm{c}}^{2}=24.50\right.$, $P<0.001)$. Of the 43 experimental group crabs which moved towards the nozzle, 35 made contact with it and attempted to feed on the water jet (Table II). Experimental group females took significantly longer to reach the nozzle than did experimental group males (Mann-Whitney $U$-test, $U=95$, males $=21$, females $=14$, 
TABLE, II

The results of olfaction experiments on Ebalia tuberosu in which individual crabs were presented with a current of water carrying food (Chlamys) extract (experimental) or not (control).

\begin{tabular}{|c|c|c|c|c|}
\hline & \multicolumn{2}{|r|}{ Control } & \multicolumn{2}{|c|}{ Experimental } \\
\hline & Males & $\begin{array}{ll}\cdots & \\
& \text { Females }\end{array}$ & Males & Females \\
\hline - & $\ldots \quad \ldots \quad \ldots$ & $\ldots \ldots$ & $\quad$. & $-\quad$ \\
\hline No. tested & 32 & 23 & 39 & 36 \\
\hline No. responded & 8 & 3 & 28 & 22 \\
\hline \multicolumn{5}{|l|}{ Final orientation: } \\
\hline towards nozzle & 3 & 2 & 24 & 19 \\
\hline away from nozzle & 5 & 1 & 4 & 13 \\
\hline No, reached nozzle & 0 & 0 & 21 & 14 \\
\hline $\begin{array}{l}\text { Mean time taken to } \\
\text { reach nozzle, }(\bar{x} \pm S D) s\end{array}$ & & & $111.14 \pm 124.95$ & $176.07 \pm 134.51$ \\
\hline
\end{tabular}

$0.04<P<0.05$ ). There was no significant correlation between carapace length of males and time taken to reach the nozzle but there was for females (males: $r=0.109$, d.f. $=19, P>0.50$; females: $r=0.555$, d.f. $=12,0.02<P<0.05$ ).

\section{DISCUSSION}

The greater part of the food of Ebalia tuberosa consists of small invertebrates disturbed when the crabs probe the sediment. Small swimming organisms are also taken when these can be captured. The majority of identifiable food items in the stomachs were indigestable parts of polychaetes and small crustaceans and probably these organisms are the main prey of the crabs. Sediment particles were found in nearly all the stomachs of E. tuberosa examined, but these were never as abundant as animal remains and the crabs were rarely observed to ingest sediment. The mouthparts of $E$. tuberosa are adapted for feeding on macromaterial (Schembri. $1980)$ and feeding on detritus is probably of minor importance to the crabs. Most of the sediment in the stomachs is probably ingested with the food. E. tuberosa is perhaps best described as a predator-scavenger.

The leucosiid Philyra laevis fecds on worms and other burrowing invertebrates which it obtains by probing mud in much the same way as Ebalia tuberosa (Hale, 1926). The leucosiid lliacanthus apparently captures swimming prey by grabbing at them with the chelae (Warner, 1977). This species seems better adapted than Ebalia for capturing prey in this way in that the chelae are more slender and finely toothed (Warner, 1977). The stalking and capture of swimming prey is not confined to leucosiids but has also been observed in other brachyurans (e.g. Hyas, Dixon \& Dixon, 1891; Macropodia, Rassmussen, 1973; Warner, 1977; Callinectes, Warner, 1977). 
Ebalia tuberosa are normally nocturnally active (Gosse, 1856; Schembri, 1980) but when stimulated by body fluids of a damaged animal leaking into the water, the crabs became active and fed during the day. Presumably, a dead or moribund animal represents a rich but transient food source that is attractive to a wide variety of scavengers. Any animal that is to exploit this must be able to detect rapidly and to locate accurately the potential food; $E$. tuberosa appears well adapted to do this.

Inactive Ebalia showed little response to either living prey or to the model worm. When food extract was present, however, the crabs became active and attacked both living and inanimate objects, provided they were moving. This suggests that the crabs are initially stimulated to feed mainly by chemical cues but that mechanical and visual cues are also important in subsequent location of the food, at least in still water. In flowing water, food is probably predominantly located chemically at long distances because the crabs moved upstream to the source of the stimulus when the current carried food extract but showed little directed response to the current when no food extract was present. In females but not in males, the larger crabs took longer to reach the nozzle than did smaller individuals. This was probably due to the greater bulk of the females causing turbulence in the confined space of the experimental chamber that confused the animals.

When stalking swimming prey and when scavenging, individuals of E. tuberosa adopted characteristic postures with the chelae stretched out in front of the body (Figs. 3 and 4). The significance of such postures is not known. One explanation may be that because the chelae of decapods carry a variety of chemo- and mechano-receptors (Laverack, 1962a,b; Shelton \& Laverack, 1968, 1970; Hindley, 1975), Ebalia may be comparing the input from the receptors on its chelae to orientate towards the stimulus source.

\section{ACKNOWLEDGEMENTS}

I am grateful to Professor J.A. Allen for providing the necessary facilities and for his interest in this work. Thanks are due to Dr. R. J.A. Atkinson for the loan of equipment and for many useful discussions. This work was carried out under tenure of a Commonwealth Scholarship awarded by the Association of Commonwealth Universities.

\section{REFERENCES}

Dixon, G. Y. \& A.F. Dixon, 1891. Report on the marine invertebrate fauna near Dublin. Proc. R. Ir. Acad., Ser. 3, Vol. 2, pp. 18-33.

GosSE, P.H., 1856. The aquarium: an unveiling of the wonders of the deep sea. John Van Voorst, London, 2nd edition, $304 \mathrm{pp}$.

Hale, H. M., 1926. Habits of the smooth pebble crab (Philyra laevis Bell). S. Aust. Nat. Adelaide, Vol. 7, pp. 67-69. 
HiND(.t ). J.P. R., 1975. The detection, location and recognition of food by juvenile banana prawns, Penaeus merguiensis de Man. Mar. Behav. Physiol., Vol. 3, pp. 193-210.

LAVERACK, M.S., 1962a. Responses of cuticular sense organs of the lobster, Homarus vulgaris (Crustacea). I. Hairpeg organs as water current receptors. Comp. Biochem. Phy:siol., Vol. 5, pp. 319-325.

LAverack, M.S., 1962b. Responses of cuticular sense organs of the lobster, Homarus vulgaris (Crustacea). II. Hairfan organs as pressure receptors. Comp. Biochem. Phvsiol. Vol. 6, pp. 137-145. RASMUSSEN, E., 1973. Systematics and ecology of the Iselfjord marine fauna. Ophclia, Vol. 11, pp. 1-495. SCHEMBRI, P. J., 1980. Aspects of the biology, behaviour and functional morphology of the crab Ebalia tuherosa (Pennant). Ph.D. thesis, University of Glasgow, Scotland, $194 \mathrm{pp}$.

SHFlton. R.G.J. \& M.S. LAverack. 1968. Observations on a redescribed crustacean sense organ. Comp. Biochem. Physiol., Vol. 25, pp. 1049-1059.

Shliton, R.G.J. \& M.S. LAverack, 1970. Receptor hair structure and function in the lobster Homarus gammarus (L.). J. exp. mar. Biol. Ecol.. Vol. 4, pp. $201-210$.

WARNER, G. F.. 1977. The hiology of crubs. Elek Science, London, $202 \mathrm{pp}$. 